\title{
Inventory of the historical Dianthus sylvestris herbarium materials from Herbarium Croaticum and Herbarium Ivo and Marija Horvat
}

\author{
ANA TERLEVIĆ*, IVANA REŠETNIK
}

University of Zagreb, Faculty of Science, Department of Biology, Division of Botany, Marulićev trg 20/ II, HR-10000 Zagreb, Croatia

*Autor za dopisivanje / corresponding author: ana.terlevic@biol.pmf.hr

Tip članka / article type: kratko znanstveno priopćenje / short scientific communication Povijest članka / article history: primljeno / received: 4.12.2019., prihvaćeno / accepted: 26.4.2020. URL: https://doi.org/10.46232/glashbod.8.1.2

Terlević, A., Rešetnik, I. (2020): Inventory of the historical Dianthus sylvestris herbarium materials from Herbarium Croaticum and Herbarium Ivo and Marija Horvat. Glas. Hrvat. bot. druš. 8(1): 8-14.

\section{Abstract}

In order to initiate a taxonomical revision of the Dianthus sylvestris group, an inventory of historical herbarium materials from ZA and ZAHO collections was conducted. Herbarium specimens of $D$. sylvestris group from these two herbaria were digitized and the data from the original herbarium labels were inserted in the Flora Croatica Database. A total of 344 herbarium sheets were digitized and six taxa (D. sylvestris Wulfen in Jacq. ssp. sylvestris, D. sylvestris ssp. tergestinus (Rchb.) Hayek, D. sylvestris ssp. longicaulis (Ten.) Greuter et Burdet, D. sylvestris ssp. nodosus (Tausch) Hayek, D. siculus C. Presl and D. arrosti C. Presl) were registered within studied collections. Inventory of herbarium sheets from ZA and ZAHO historical collections provided a significant insight into historical distributional data of $D$. sylvestris taxa related to the area of the Balkan Peninsula, which is a prerequisite for accurate taxonomic/ geographic sampling for further morphological and molecular analyses.

Keywords: Balkan Peninsula, digitization, distribution, Flora Croatica Database

Terlević, A., Rešetnik, I. (2020): Pregled povijesnog herbarijskog materijala vrste Dianthus sylvestris u zbirkama Herbarium Croaticum i Herbarij Ive i Marije Horvat. Glas. Hrvat. bot. druš. 8(1): 8-14.

\section{Sažetak}

Kako bi se započelo s taksonomskom revizijom grupe svojti koje pripadaju Dianthus sylvestris, provedeno je popisivanje povijesnog herbarijskog materijala iz zbirki ZA i ZAHO. Herbarijski primjerci vrsta koje pripadaju grupi $D$. sylvestris su digitalizirani, a podaci s originalnih herbarijskih etiketa su uneseni u bazu podataka Flora Croatica. Digitalizirano je ukupno 344 herbarijskih listova i zabilježeno je šest svojti (D. sylvestris Wulfen in Jacq. ssp. sylvestris, D. sylvestris ssp. tergestinus (Rchb.) Hayek, D. sylvestris 
ssp. longicaulis (Ten.) Greuter et Burdet, D. sylvestris ssp. nodosus (Tausch) Hayek, D. siculus C. Presl i D. arrosti C. Presl). Popisivanje herbarijskih listova ovih svojti iz ZA i ZAHO pruža uvid u povijesne podatke o rasprostranjenosti svojti iz grupe $D$. sylvestris na području balkanskog poluotoka, što je preduvjet za ispravno taksonomsko/geografsko uzorkovanje za daljnje morfološke i molekularne analize.

Ključne riječi: Balkan, baza podataka Flora Croatica, digitalizacija, rasprostranjenost

\section{Introduction}

Dianthus sylvestris group is considered to be one of the most complex groups within the genus Dianthus L. (Caryophyllaceae). An important diversity centre is the central Mediterranean area (Balkan and Apennine Peninsula) where the number of taxa belonging to this group is high. They mainly occur in rupestrian habitats, as well as on rocky and sunny grasslands, garigues, steppes and mesic meadows (Bacchetta et al. 2010). Real taxonomical value of taxa belonging to this group is often doubtful, and synonymy confusion is common. The group is morphologically characterized by woody stocks, shortly branched, usually with dense terminal leaf rosettes, linear and acute leaves, flowers not or slightly fragrant, arranged in loose cymes, epicalyx scales 2-6(-8), glabrous, abruptly contracted into a short mucro, 3-5 times shorter than calyx, glabrous petals with limb denticulate at apex or entire (Pignatti 1982, Tutin \& Walters 1993). Subspecies listed by Marhold (2011), regarding the Euro-Mediterranean area, are Dianthus sylvestris ssp. bertisceus Rech. f., D. sylvestris ssp. kozjakensis Micevski, D. sylvestris ssp. longicaulis (Ten.) Greuter et Burdet, D. sylvestris ssp. nodosus (Tausch) Hayek, D. sylvestris ssp. siculus (C. Presl) Tutin, D. sylvestris ssp. tergestinus (Rchb.) Hayek and D. sylvestris ssp. sylvestris. In addition, D. sylvestris ssp. alboroseus F.K. Meyer, a pale pink to white flowering form, was described from southern Albania (Meyer 2011). According to Bacchetta et al. (2010), in central and southern Italy, Sardinia and Sicily this group is represented by 17 morphologically and ecologically well differentiated species.

The D. sylvestris group is very polymorphic and no reasonable key on subspecific level can be presented. Since an in-depth taxonomical review of this group needs to be done, the first step is to analyse the existing herbarium data from ZA (Herbarium Croaticum) and ZAHO (Herbarium of Ivo and Marija Horvat) collections. Therefore, the aim of this article is to present: (i) an update of the distribution data based on herbarium data, (ii) taxa analysis in terms of spatial distribution, collectors and collecting dates.

\section{Materials and methods}

The herbarium specimens of $D$. sylvestris group were searched for and used for the purpose of digitization within two Croatian herbaria, ZA and ZAHO (acronyms are according to Thiers 2019). A regular procedure within these herbaria include the following steps: mounting, systematisation and digitization. According to Šegota et al. (2017), first the plant material was placed on a new paper, mounted with $\mathrm{pH}$ neutral adhesive tape on herbarium sheets while the herbarium labels were glued with Gaylord pH neutral white adhesive. The original metadata for $D$. sylvestris group herbarium sheets were inserted within the Flora Croatica Database (Nikolić 2019). The metadata include: herbarium ID, taxon name, locality, habitat, geographical coordinates, collector(s) and identifier(s) name, and collection dates. Most of these data were provided from the original label's text, while data such as geographical coordinates were derived from an up-to-date interpretation of collection locality. Finally, the prepared sheets were scanned using available scanning equipment (inversed Epson Expression 11000XL Pro A3 scanner) with the image resolution of $300 \mathrm{dpi}$ (tiff). A stamp with the ZA 

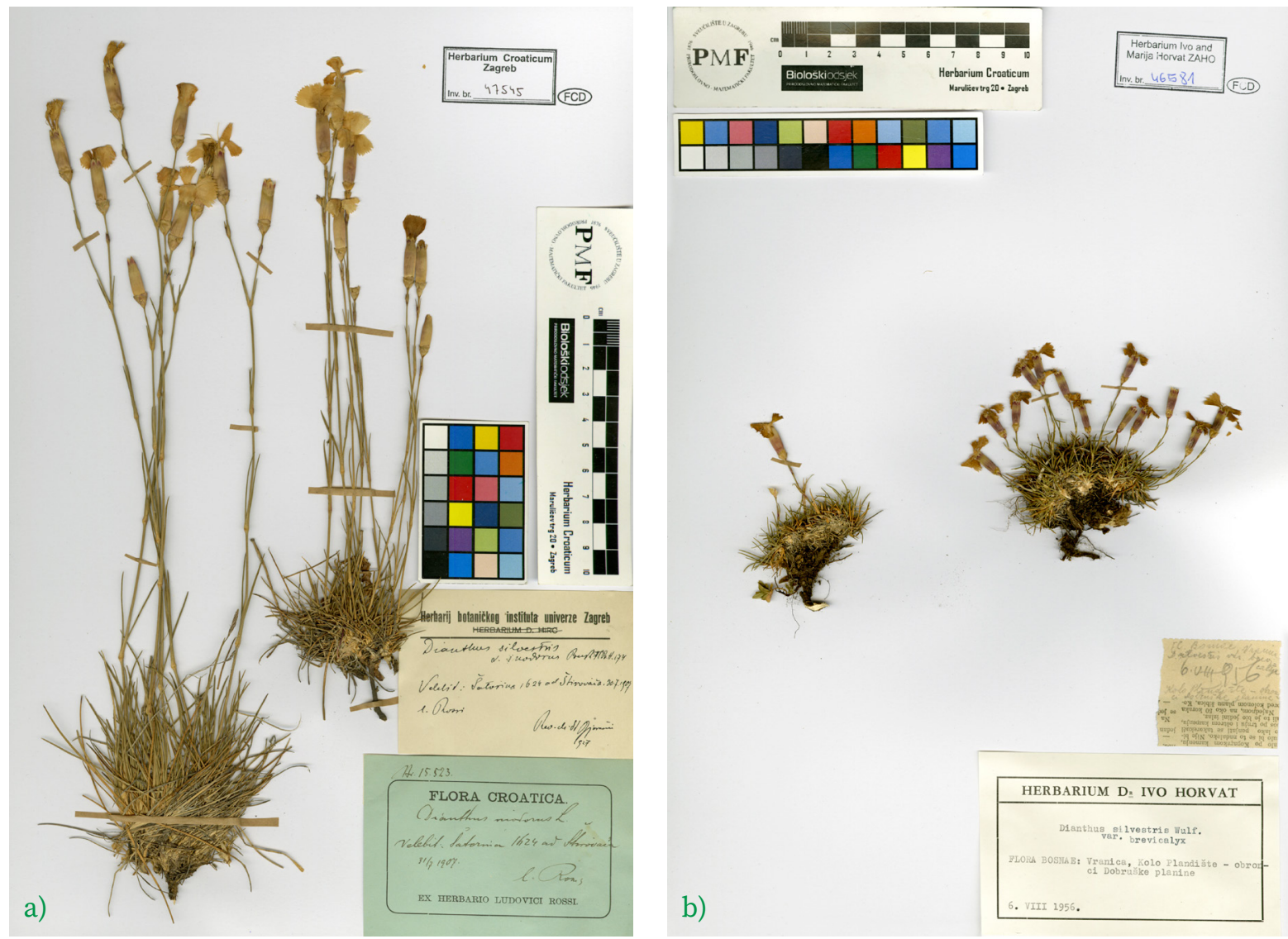

Figure 1. Herbarium sheets of Dianthus sylvestris group taxa after digital imaging, (a) ZA 47545, (b) ZAHO 46581.

and ZAHO herbarium ID, colour plate and ruler were added to each sheet prior to scanning (Fig. 1). Finally, the images were uploaded in the Flora Croatica Database and are accessible on virtual portal of the Herbarium Croaticum.

\section{Results and discussion}

In total, 344 herbarium sheets were found and digitized within the two studied collections. In the ZA Herbarium Generale (collection formed via exchange with other world herbaria) 25 specimens of $D$. sylvestris group were discovered. The ZA collection holds 207 herbarium sheets (60\%) and ZAHO collection holds 137 sheets (40\%). Altogether, six taxa belonging to $D$. sylvestris group were registered, four of them being native to Croatia. Specimens determined as D. sylvestris s.l. occurred on the largest number of herbarium sheets (235), followed by D. sylvestris ssp. tergestinus (69), D. sylvestris ssp. nodosus (33), D. sylvestris ssp. longicaulis (3), D. arrosti C. Presel (2), D. siculus C. Presel (1) and D. sylvestris ssp. sylvestris (1) (Tab. 1).

Dianthus arrosti and D. siculus are not native to Croatia. The species D. arrosti occurs in Sicily, Sardinia and southern Calabria (Bacchetta et al. 2010), and according to Marhold (2011) it is also native to Algeria and Morocco. One herbarium specimen found in ZA Herbarium Generale originates from Dr. L. Nicotra - Herbarium Siculum (PAL, Palermo, Italy), and the other from Dr. C. Baenitz, Herbarium Europeum (MNHM, Paris, France). However, locality descriptions on herbarium labels are not clear. D. siculus is common in Italy, Corse, Spain, Morocco, Algeria and Tunisia (Bacchetta et al. 2010, Marhold 2011). In Euro+Med PlantBase (Marhold 2011) it is registered as D. sylvestris ssp. 
Table 1. The number of digitized herbarium sheets for each taxon across the studied collections.

$\begin{array}{lcccc}\text { Taxon name } & \text { ZA } & \text { ZAHO } & \text { total } \\ \text { Dianthus sylvestris Wulfen in Jacq. } & 103 & 132 & 235 \\ \text { Dianthus sylvestris Wulfen in Jacq. ssp. tergestinus (Rchb.) Hayek } & 66 & 3 & 69 \\ \text { Dianthus sylvestris Wulfen in Jacq. ssp. nodosus (Tausch) Hayek } & 32 & 1 & 33 \\ \text { Dianthus sylvestris Wulfen in Jacq. ssp. longicaulis (Ten.) Greuter et Burdet } & 3 & 0 & 3 \\ \text { Dianthus arrosti C. Presl } & 2 & 0 & 2 \\ \text { Dianthus sylvestris Wulfen in Jacq. ssp. sylvestris } & 0 & 1 & 1 \\ \text { Dianthus siculus C. Presl } & 1 & 0 & 1 \\ \text { Grand total } & \mathbf{2 0 7} & \mathbf{1 3 7} & \mathbf{3 4 4}\end{array}$

siculus (C. Presl) Tutin. The single herbarium specimen found in ZA Herbarium Generale originate from the collection of O. Debeaux - Plantes d’Algerie.
Herbarium specimens originate from 12 European countries and from Algeria (Fig. 2); however, the majority were collected in Croatia (57\%). As much as 23 herbarium sheets in ZA, and 7 herbarium sheets in ZAHO collection could not be georeferenced

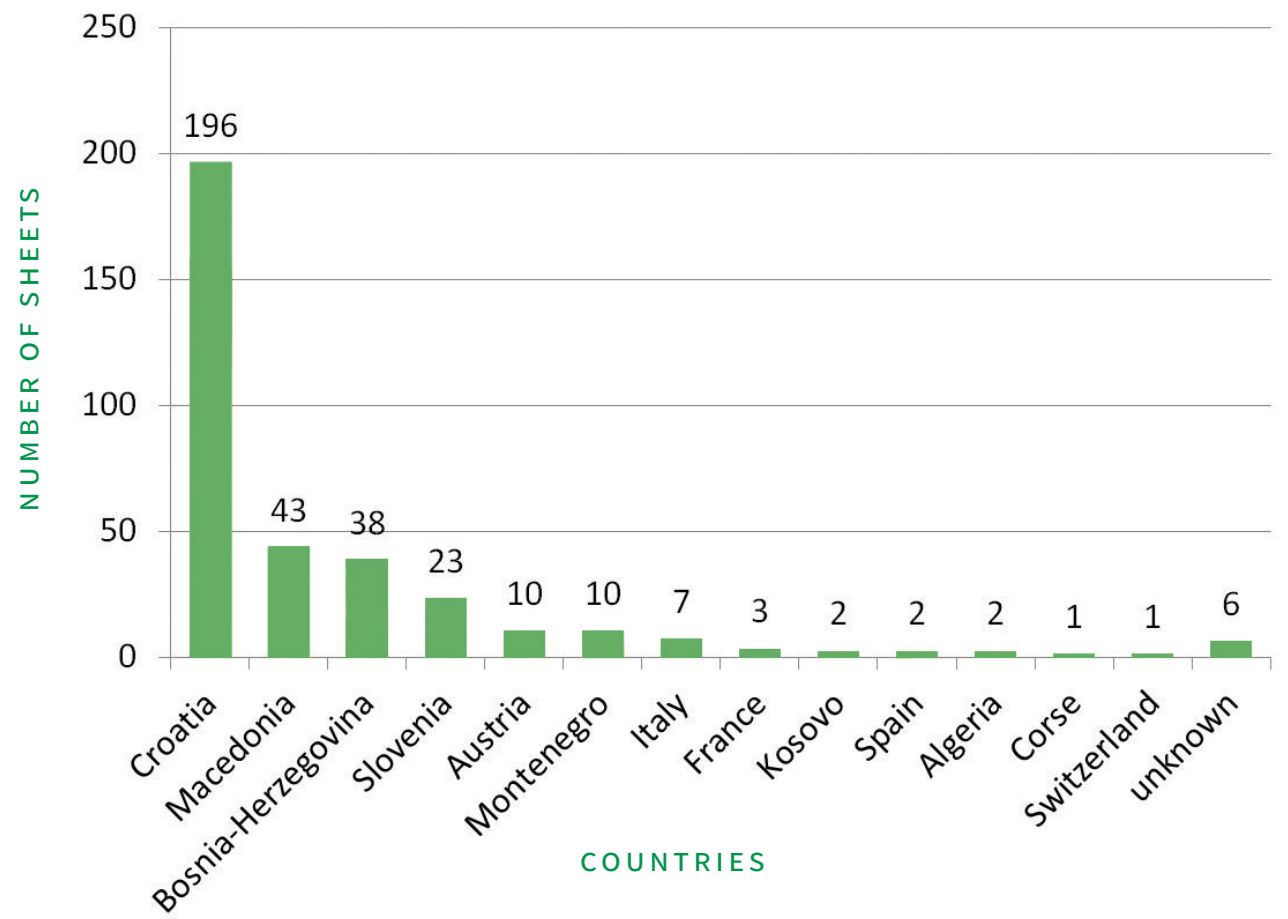

Figure 2. Geographical origin of D. sylvestris group herbarium specimens stored across studied collections. 

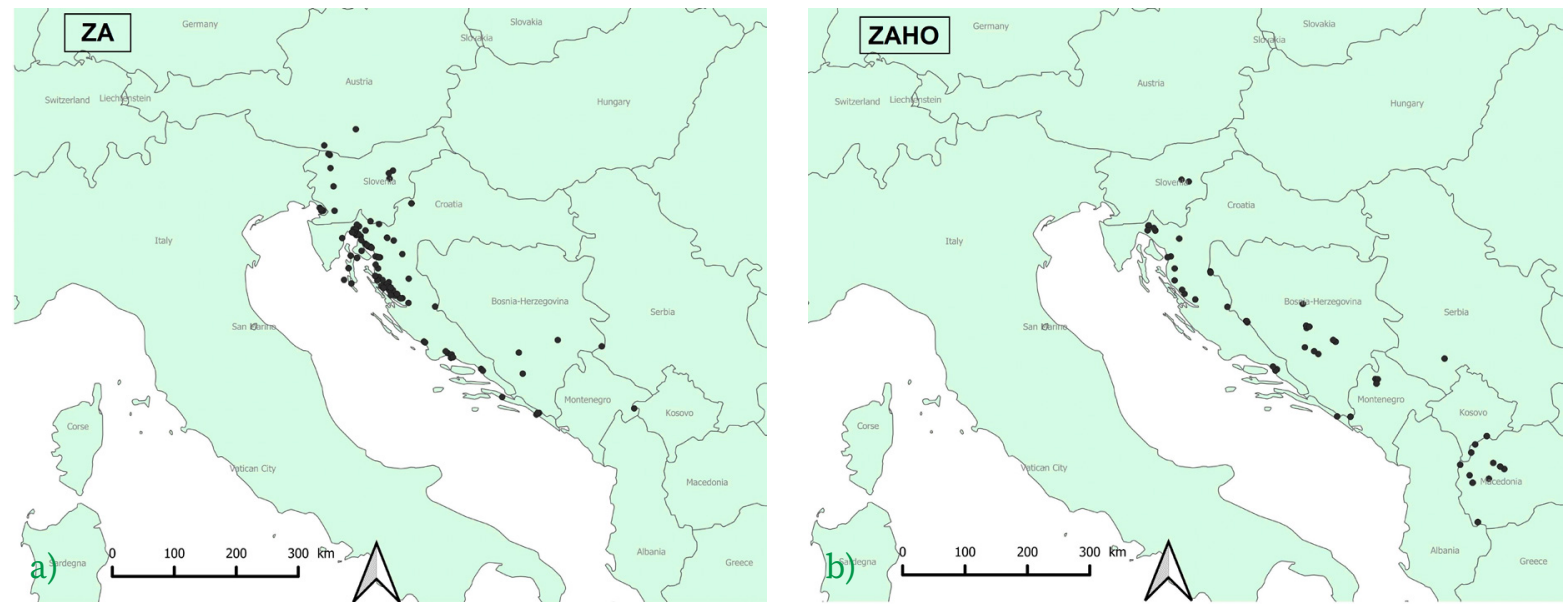

Figure 3. Distribution maps of D. sylvestris group herbarium specimens from (a) ZA and (b) ZAHO collection.

due to ambiguous locality description or due to the lack of any locality description, except the country. Likewise, all of the 25 herbarium sheets from Herbarium Generale have not been georeferenced for the same reasons. Regarding the Croatian territory, the collection sites of taxa are localized mostly on Mt Velebit, which reflects field activities of collectors of those two collections (Fig. 3). The distribution of taxa in Croatia based on historical herbarium data (Fig. 4) showed overlaps with the field record data made by the authors during 2018 and 2019 fieldworks (location data not shown).

The most productive collector of the studied herbarium materials was Ivo Horvat, the lone collector of ZAHO, with 135 herbarium sheets. Ljudevit Rossi stored 40 herbarium sheets in ZA, Dragutin Hirc 30, Ivo Pevalek 17, Josip Klasancije Schlosser 13,
Ljudevit Vukotinović 12, while other 44 collectors contributed with less than 10 herbarium sheets each. The majority of specimens were collected between 1910s and 1940s (Fig. 5) which is in line with the previous reports (Strgulc Krajšek et al. 2009, Šegota et al. 2017). As much as 49 herbarium specimens lack data on collecting period, i.e. the year of collecting was either missing from the label or it was illegible. The oldest specimen kept at ZAHO was collected in 1920, whereas the oldest specimens from ZA date back to 1853 for Herbarium Generale (unknown collector), and to 1852 for the main ZA collection (specimen collected by $\mathrm{Lj}$. Vukotinović and K. Schlosser).

Taxa of $D$. sylvestris group which have not been found in ZA and ZAHO collections, but are known from the Balkan Peninsula, are D. sylvestris ssp.
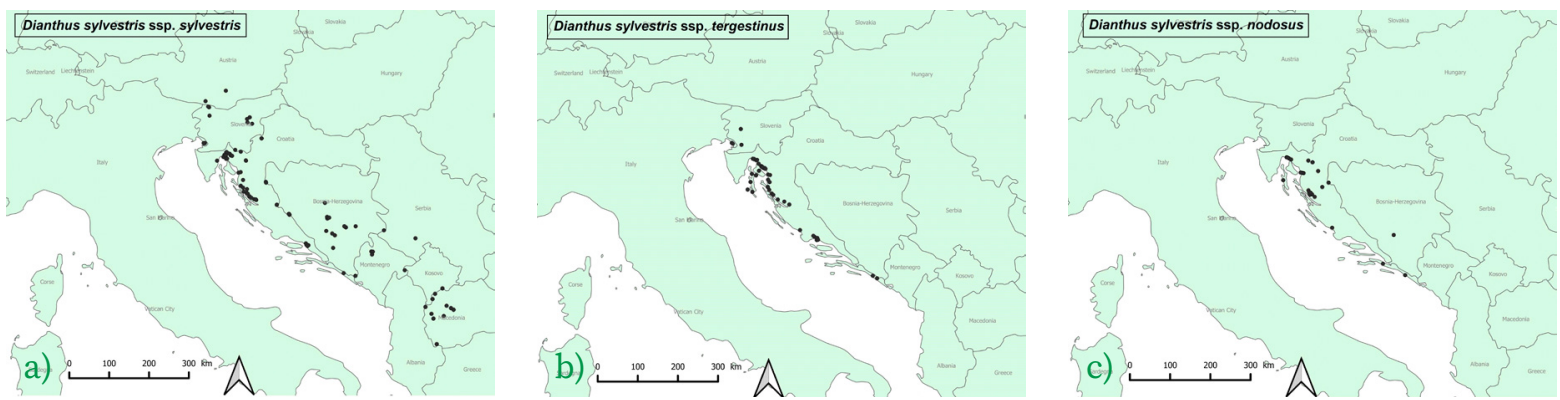

Figure 4. Individual distribution maps for (a) D. sylvestris (including the single herbarium specimen stored as D. sylvestris Wulfen in Jacq. ssp. sylvestris), (b) D. sylvestris ssp. tergestinus, and (c) D. sylvestris ssp. nodosus stored across studied collections. 


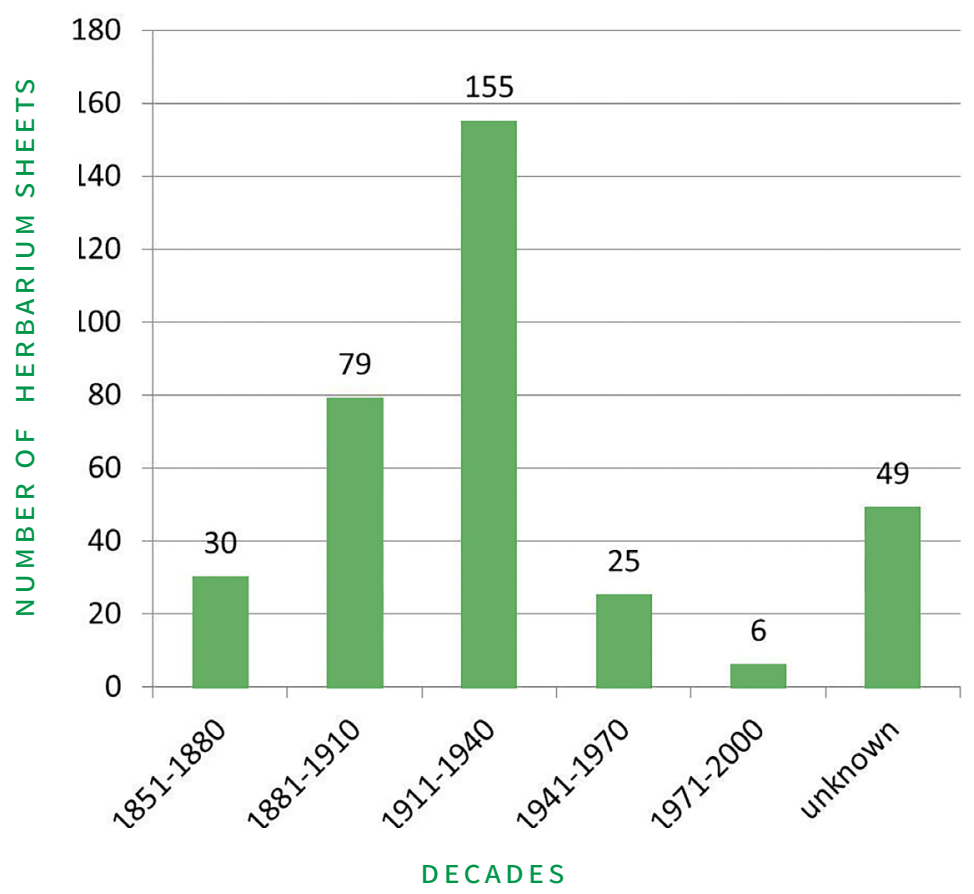

Figure 5. Temporal distribution of the herbarium specimens based on collection period shown in decadal scale.

alboroseus, D. sylvestris ssp. bertisceus and D. sylvestris ssp. kozjakensis. However, these taxa have rather restricted distribution areas that were rarely covered by field activities of main ZA collectors. Moreover, taxa D. sylvestris ssp. kozjakensis and D. sylvestris ssp. alboroseus were described only recently by Micevski (1990) and Meyer (2011), respectively.

These results represent the current state of $D$. sylvestris group taxa composition within ZA and ZAHO collections. Apart from historical herbarium specimens, D. sylvestris collections from ZA have recently been growing due to extensive sampling of D. sylvestris taxa throughout the Balkans (Croatia and neighbouring countries). Sampling of $D$. sylvestris material for morphological and molecular analysis is under way, in order to resolve taxonomic, phylogenetic as well as phylogeographic relationships among taxa. After the morphological characterisation of taxa, it will be possible to carry out a thorough taxonomic revision, from which a different view on taxa composition in these herbaria could be obtained.

\section{Acknowledgment}

This work has been supported in part by Croatian Science Foundation under the project UIP-201705-2882 (AmphiAdriPlant). The work of doctoral student Ana Terlević has been fully supported by the "Young researchers' career development project - training of doctoral students" of the Croatian Science Foundation funded by the European Union from the European Social Fund. Authors are grateful to students Marina Babić, Ana Kordić and Petra Stić for their help during material digitizing process.

\section{References}

Bacchetta, G., Brullo, S., Casti, M., Pietro Giusso del Galdo, G. (2010): Taxonomic revision of the Dianthus sylvestris group (Caryophyllaceae) in central-southern Italy, Sicily and Sardinia. Nordic Journal of Botany 28(2): 137-173.

Horvat, M., Plazibat, M. (2007): Prikaz Horvatova herbarija (ZAHO) u Zagrebu. Natura Croatica 16(4): 267-408.

Strgulc Krajšek, S., Šegedin, T., Jogan, N. (2009): 
Revision of Epilobium and Chamerion in the Croatian herbaria ZA and ZAHO. Natura Croatica 18 (1): 155-167.

Marhold, K. (2011): Caryophyllaceae. In: Euro+Med Plantbase - the information resource for Euro-Mediterranean plant diversity. http://ww2.bgbm. org/EuroPlusMed/ (accessed October 12, 2019).

Meyer, F. K. (2011): Beiträge zur Flora von Albanien. Haussknechtia Beih 15: 1-220.

Micevski, K. (1990): Novitäten in der Gattung Dianthus L. (Caryophyllaceae) in der Flora der SR Makedonien. Prilozi, Oddelenie za Bioloshki i Meditsinski Nauki. Makedonska Akademija na Naukite i Umetnostite 8(1-2): 31-46.

Micevski, K. (1993): Flora na Republika Makedonija, 1,2. Macedonian Academy of Sciences and Arts. Skopje: 153-391.

Nikolić, T. (ed.) (2019): Flora Croatica database. Department of Botany, Faculty of Science, University of Zagreb. http://hirc.botanic.hr/fcd (accessed October 12, 2019).

Pignatti, S. (1982): Flora d'Italia, 1. Edagricole,
Bologna, 265-273.

Strgulc Krajšek, S., Šegedin, T. i Jogan, N. (2009): Revision of Epilobium and Chamerion in the Croatian herbaria ZA and ZAHO. Natura Croatica 18(1): 155-167.

Šegota, V., Buzjak, S., Vilović, T., Sedlar, Z., Rešetnik, I., Bogdanović, S. (2017): Curators in action: intricate genus Fritillaria L. (Liliaceae) from ZA, ZAHO, CNHM and ZAGR revised and digitized. Glasnik Hrvatskog Botaničkog Društva 5(2): 4-14.

Thiers, B. (2017): Index Herbariorum. A global directory of public herbaria and associated staff. New York Botanical Garden's Virtual Herbarium. http:// sweetgum.nybg.org/ih/ (accessed October 2019).

Trinajstić, I. (1979): Analitička flora Jugoslavije. Svezak 1, Broj 5: 732-734.

Tutin, T. G., Walters, S. M. (1993): Carex L. In: Tutin, T. G., Heywood, V. H., Burges, N. A., Moore, D. M., Valentine, D. H., Walters, S. M., Webb, D. A. (eds.): Flora Europaea 1. Cambridge University Press, Cambridge, 227-240. 